\title{
Corrigendum
}

\section{Use of gentian violet to differentiate in vitro and ex vitro-formed roots during acclimatization of grapevine}

\author{
I. Gribaudo ${ }^{1}$, M. Asuncion Morte ${ }^{2, *} \&$ Andrea Schubert ${ }^{2}$
}

${ }^{1}$ Centro Miglioramento Genetico e Biologia Vite CNR, Via Giuria 15, 10126 Torino, Italy; ${ }^{2}$ Dipartimento Colture Arboree dell'Universitd, Via Giuria 15, 10126 Torino, Italy (" present address: Departamento Biologia Vegetal, Universidad de Murcia, Campus de Espinardo, 30100 Murcia, Spain)

Plant Cell, Tissue and Organ Culture 41: 187-188, 1995

The submitted original title of this publication was:

Development of in vitro and ex vitro-formed roots during acclimatization of grapevine 